\title{
Is the use of microwave ablation more effective and/or safe that radiofrequency ablation in the treatment of hepatocellular carcinoma?
}

\author{
Participants: \\ Adriano Anzai ${ }^{1}$ \\ Armelin Utino ${ }^{1}$ \\ Haroldo Katayama ${ }^{1}$ \\ Ighor A. Z. Spir ${ }^{1}$ \\ Marcio A. Lemos ${ }^{1}$ \\ Mary Martins Nery ${ }^{1}$ \\ Mauricio Anhesini ${ }^{1}$ \\ Oswaldo S. Tiezzi \\ Patricia R. N. Spir ${ }^{1}$ \\ Pericles Otani ${ }^{1}$ \\ Wanderley M. Bernardo ${ }^{2}$
}

Created on: 22 May, 2020

1. Programa Diretrizes da Associação Médica Brasileira, São Paulo, SP, Brasil 2. Coordenador do Programa Diretrizes da Associação Médica Brasileira, São Paulo, SP, Brasil

E-mail: wmbernardo@usp.br

http://dx.doi.org/10.1590/1806-9282.66.4.392

The Guidelines Project, an initiative of the Brazilian Medical Association, aims to combine information from the medical field in order to standardize producers to assist the reasoning and decision-making of doctors.

The information provided through this project must be assessed and criticized by the physician responsible for the conduct that will be adopted, depending on the conditions and the clinical status of each patient.

\section{INTRODUCTION}

Liver cancer can be of two types: primary (which begins at the organ itself) and secondary or metastatic (originating in another organ and, with the progression of the disease, also affecting the liver). The secondary type is most often due to a malignant tumor in the large intestine or rectum.

Among the types of primary liver cancer, the most common is the hepatocellular carcinoma - an extremely aggressive tumor that presents several risk factors, the main ones being cirrhosis and chronic diseases such as infections by the hepatitis $B$ and $C$ virus.

The ideal management of this type of tumor depends on many factors, including their size, the number of lesions, the distribution of the tumor, the relationship between the tumor and hepatic vascularization, the presence or absence of distant metastasis or lymph nodes, the Child-Pugh score ${ }^{1}$, the functional status of the patient, and the adequacy to a liver transplant.

When the tumor is small, the treatment consists of surgically removing the tumor and part of the liver, provided that the function of the organ is preserved; if these criteria are not present, the alternative is liver transplantation.

There are, however, other treatment options, which are considered more conservative, among 
them is cryosurgery (freezing of the malignant cells), tumor ablation by radiofrequency - RFA (electrical waves cause an increase of the temperature inside the tumor), microwave ablation - MWA, alcoholization (injection of alcohol into the tumor), and chemoembolization (application of microspheres containing chemotherapeutic agents).

For hepatocellular carcinomas of 4 to $5 \mathrm{~cm}$ or less, radiofrequency ablation presents good results and few complications. This same procedure can be performed using microwaves, with a shorter duration, higher temperature, and larger ablation zone, with the possibility of using multiple probes, and with less heat dissipation through the liver.

The goal of this assessment is to compare the efficacy and safety of microwave ablation in comparison with radiofrequency ablation in the treatment of hepatocellular carcinoma.

\section{METHODS}

In the methodology, we present the clinical question, the structured question (PICO), the eligibility criteria, the sources of information and search strategies used, the method for critical assessment (risk of bias) and quality of evidence (GRADE ${ }^{2}$ ), the data to be extracted, the measures used to express the results, and the method of analysis.

\section{Clinical Question}

Is the treatment of hepatocellular carcinoma more effective and/or safe with the use of microwave ablation than with radiofrequency ablation?

\section{Structured question}

\begin{tabular}{l|l}
\hline $\mathbf{P}$ & (Population): Patients with hepatocellular carcinoma \\
\hline $\mathbf{I}$ & (Intervention): Microwave ablation \\
\hline $\mathbf{C}$ & (Comparison): Radiofrequency ablation \\
\hline $\mathbf{O}$ & $\begin{array}{l}\text { (Outcome): local recurrence, mortality, lession progression, } \\
\text { and complications }\end{array}$ \\
\hline
\end{tabular}

Eligibility criteria

- PICO components;

- Randomized clinical trials (RCTs);

- No time restrictions;

- English, Spanish, and Portuguese languages;

- Full text or summary with the necessary data;

- Outcomes expressed as the absolute number of events or mean/median with variation

\section{Exclusion criteria}

- Observational and non-comparative studies.

- In vitro and/or animals studies.

- Case series or case reports.

- Narrative or systematic reviews.

Sources of information consulted and search strategies

Medline via PubMed, EMBASE, and manual search

\#1: (Liver Neoplasm OR Hepatic Neoplasms OR Hepatic Neoplasm OR Hepatocellular Cancer OR Hepatocellular Cancers OR Hepatic Cancer OR Hepatic Cancers OR Liver Cancer OR Liver Cancers OR Hepatocellular Carcinomas OR Liver Cell Carcinoma OR Liver Cell Carcinomas OR Hepatocellular Carcinoma OR Hepatoma OR Hepatomas)

\#2: (Radiofrequency OR Radio Frequency OR Catheter Ablation)

\#3: (Microwave OR Waves OR Wave)

\#4: (\#1 OR \#2 OR \#3)

\#5: \#4 AND random*

\section{Risk of bias and quality of evidence}

For RCTs, we assessed the following risks of bias: randomization, blinding, double-blinding, blinding of the evaluator, losses, analysis by intention to treat (ITT), definition of the outcomes and sample size calculation, early interruption.

\section{Extracted data}

Author, Year of publication, study design, characteristics and number of patients, intervention, comparison, outcomes (local recurrence, mortality, lesion progression, and complications).

\section{Outcome measures}

For the variables, we used absolute numbers, percentage, absolute risk, reduction or increase of risk, the number needed to treat (NNT) or to harm (NNH), confidence interval of $95 \%$ (95\% CI).

\section{Presentation of the results}

If there is the possibility to combine the results of the studies included regarding one or more shared outcomes, a meta-analysis will be carried outcome. [RevMan 5.3 software (Cochrane)] $]^{3}$.

\section{Analysis of the quality of evidence}

The quality of the evidence was assessed by using the GRADE ${ }^{2}$ (GRADEpro software) ${ }^{4}$. 


\section{RESULTS}

The results presented are: diagram of recovery and selection of studies (Figure 1), characteristics of the studies (Table 1), risks of bias (Table 2), results by outcomes (Table 3), quality of evidence (Table 4), and synthesis of evidence.
We retrieved 126 studies; after applying the eligibility criteria, 18 studies were selected, of which 09 were included ( 07 for full-text evaluation and 2 for abstract evaluation) (Figure 1). The list of studies excluded is available in Table 5.

TABLE 1. DESCRIPTION OF THE WORKS

\begin{tabular}{l|l|l|l|l|l|l|l} 
Author/year & PIMD & $\begin{array}{l}\text { Type of } \\
\text { design }\end{array}$ & $\begin{array}{l}\text { Popula- } \\
\text { tion (n) }\end{array}$ & $\begin{array}{l}\text { Interven- } \\
\text { tion (n) }\end{array}$ & $\begin{array}{l}\text { Compari- } \\
\text { son (n) }\end{array}$ & $\begin{array}{l}\text { Outcome } \\
\text { time }\end{array}$ \\
\hline Kamal 2019 & 31183208 & RCT & 56 & 28 & 28 & $\begin{array}{l}\text { local recurrence / mortality / complica- } \\
\text { tions }\end{array}$ & months \\
\hline Vietti Violi 2018 & 29503247 & RCT & 152 & 76 & 76 & $\begin{array}{l}\text { local recurrence / mortality / complica- } \\
\text { tions }\end{array}$ & 24 months \\
\hline Yu.J 2017 & 27884919 & RCT & 403 & 203 & 200 & $\begin{array}{l}\text { local recurrence / mortality / complica- } \\
\text { tions }\end{array}$ & 36 months \\
\hline Shibata 2002 & 11997534 & RCT & 72 & 36 & 36 & local recurrence / complications \\
\hline Abdelaziz 2014 & 24935203 & RCT & 111 & 66 & 45 & $\begin{array}{l}\text { local recurrence / survival / complica- } \\
\text { tions }\end{array}$ & 27 months \\
\hline Di Vece F 2014 & 24196263 & RCT & 40 & 20 & 20 & Complications \\
\hline Sheta E 2016 & 27362551 & RCT & 30 & 10 & 20 & Complications / local recurrence \\
\hline Naïk VV 2017 & & RCT & 144 & 71 & 73 & Progression / survival (mortality) \\
\hline Chong C 2017 & & RCT & 81 & 40 & 41 & Local recurrence / survival (mortality) & 6 months \\
\hline
\end{tabular}

RCT = RANDOMIZED CLINICAL TRIAL

TABLE 2. RISKS OF BIAS

\begin{tabular}{|c|c|c|c|c|c|c|c|c|c|}
\hline Author/year & $\begin{array}{l}\text { Random- } \\
\text { ization }\end{array}$ & $\begin{array}{l}\text { Blinded } \\
\text { allocation }\end{array}$ & $\begin{array}{l}\text { Dou- } \\
\text { ble-blind }\end{array}$ & Losses & Prognosis & Outcome & $\begin{array}{l}\text { Inten- } \\
\text { tion-treat } \\
\text { analysis }\end{array}$ & $\begin{array}{l}\text { Sample } \\
\text { size cal- } \\
\text { culation }\end{array}$ & $\begin{array}{l}\text { Early ter- } \\
\text { mination }\end{array}$ \\
\hline \multicolumn{10}{|l|}{ Kamal 2019} \\
\hline \multicolumn{10}{|l|}{ Vietti Violi 2018} \\
\hline \multicolumn{10}{|l|}{ Yu.J 2017} \\
\hline \multicolumn{10}{|l|}{ Shibata 2002} \\
\hline \multicolumn{10}{|l|}{ Abdelaziz 2014} \\
\hline \multicolumn{10}{|l|}{ Di Vece F 2014} \\
\hline \multicolumn{10}{|l|}{ Sheta E 2016} \\
\hline \multicolumn{10}{|l|}{ Naïk VV 2017} \\
\hline Chong C 2017 & & & & & & & & & \\
\hline
\end{tabular}

Blue: Absence of biases; Yellow: Unknow; Orange: Presence of biases

TABLE 3. RESULTS OF THE OUTCOMES

\begin{tabular}{|c|c|c|c|c|c|c|c|c|c|c|c|}
\hline \multirow{2}{*}{\multicolumn{3}{|c|}{$\begin{array}{l}\text { Microwave } \\
\text { Radiofrequency }\end{array}$}} & \multicolumn{2}{|c|}{ local recurrence } & \multicolumn{2}{|c|}{ Mortality } & \multicolumn{2}{|c|}{ Complications } & \multicolumn{2}{|c|}{$\begin{array}{l}\text { Progression of } \\
\text { the disease }\end{array}$} & \multirow[t]{2}{*}{$\begin{array}{l}\text { Follow-up } \\
\text { time }\end{array}$} \\
\hline & & & \multirow{2}{*}{$\begin{array}{l}\text { Micro- } \\
\text { wave } \\
2\end{array}$} & \multirow{2}{*}{$\begin{array}{l}\text { Radiofre- } \\
\text { quency } \\
2\end{array}$} & \multirow{2}{*}{$\begin{array}{l}\text { Micro- } \\
\text { wave } \\
4\end{array}$} & \multirow{2}{*}{$\begin{array}{l}\text { Radiof- } \\
\text { requency }\end{array}$} & \multirow{2}{*}{$\begin{array}{l}\text { Micro- } \\
\text { wave } \\
4\end{array}$} & \multirow{2}{*}{ 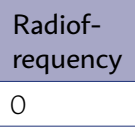 } & & & \\
\hline Kamal 2019 & 28 & 28 & & & & & & & - & - & 12 months \\
\hline Vietti Violi 2018 & 76 & 76 & - & - & 15 & 15 & - & - & 6 & 12 & 24 months \\
\hline Yu.J 2017 & 203 & 200 & - & - & 37 & 38 & 7 & 5 & 9 & 12 & 36 months \\
\hline Shibata 2002 & 36 & 36 & 4 & 1 & - & - & 1 & 4 & - & - & 24 months \\
\hline Abdelaziz 2014 & 66 & 45 & 3 & 7 & 5 & 9 & 5 & 2 & & & 27 months \\
\hline Di Vece F 2014 & 20 & 20 & & & & & 1 & 1 & & & Not informed \\
\hline Sheta E 2016 & 10 & 20 & 1 & 2 & a & & 1 & 2 & & & 6 months \\
\hline Naïk VV 2017 & 71 & 73 & & & 8 & 9 & 2 & 0 & 6 & 7 & 20 months \\
\hline Chong C 2017 & 40 & 41 & 23 & 21 & 15 & 22 & & & & & 6 months \\
\hline
\end{tabular}


TABLE 4. MICROWAVE ABLATION COMPARED TO RADIOFREQUENCY ABLATION FOR HEPATOCELLULAR CARCINOMA

\begin{tabular}{|c|c|c|c|c|c|c|c|c|c|c|c|c|}
\hline \multicolumn{7}{|c|}{ Certainty assessment } & \multicolumn{2}{|c|}{ \# of patients } & \multicolumn{2}{|l|}{ Effect } & \multirow[t]{2}{*}{ Certainty } & \multirow{2}{*}{$\begin{array}{l}\text { Impor- } \\
\text { tance }\end{array}$} \\
\hline $\begin{array}{l}\text { \# of } \\
\text { stud- } \\
\text { ies }\end{array}$ & $\begin{array}{l}\text { Design } \\
\text { of the } \\
\text { study }\end{array}$ & $\begin{array}{l}\text { Risk of } \\
\text { bias }\end{array}$ & $\begin{array}{l}\text { Incon- } \\
\text { sistency }\end{array}$ & $\begin{array}{l}\text { Indirect } \\
\text { evidence }\end{array}$ & $\begin{array}{l}\text { Impreci- } \\
\text { sion }\end{array}$ & $\begin{array}{l}\text { Other } \\
\text { consid- } \\
\text { erations }\end{array}$ & $\begin{array}{l}\text { Micro- } \\
\text { wave } \\
\text { ablation }\end{array}$ & $\begin{array}{l}\text { Radiof- } \\
\text { requency } \\
\text { ablation }\end{array}$ & $\begin{array}{l}\text { Relative } \\
(95 \% \\
\mathrm{Cl})\end{array}$ & $\begin{array}{l}\text { Absolute } \\
(95 \% \mathrm{Cl})\end{array}$ & & \\
\hline \multicolumn{13}{|c|}{ LOCAL RECURRENCE } \\
\hline 4 & $\begin{array}{l}\text { ran- } \\
\text { domized } \\
\text { clinical } \\
\text { trials }\end{array}$ & $\begin{array}{l}\text { very } \\
\text { severe a }\end{array}$ & $\begin{array}{l}\text { not } \\
\text { severe }\end{array}$ & $\begin{array}{l}\text { not } \\
\text { severe }\end{array}$ & $\begin{array}{l}\text { very } \\
\text { severe b }\end{array}$ & none & $\begin{array}{l}30 / 114 \\
(26.3 \%)\end{array}$ & $\begin{array}{l}26 / 125 \\
(20.8 \%)\end{array}$ & $\begin{array}{l}\text { not esti- } \\
\text { mable }\end{array}$ & \begin{tabular}{|l|}
40 less \\
per 1,000 \\
(from 120 \\
less to 30 \\
more)
\end{tabular} & $\begin{array}{l}\oplus O O O \\
\text { VERY } \\
\text { LOW }\end{array}$ & $\begin{array}{l}\text { IM- } \\
\text { PORT- } \\
\text { ANT }\end{array}$ \\
\hline \multicolumn{13}{|c|}{ COMPLICATIONS } \\
\hline 5 & $\begin{array}{l}\text { ran- } \\
\text { domized } \\
\text { clinical } \\
\text { trials }\end{array}$ & $\begin{array}{l}\text { very } \\
\text { severe a }\end{array}$ & $\begin{array}{l}\text { not } \\
\text { severe }\end{array}$ & $\begin{array}{l}\text { not } \\
\text { severe }\end{array}$ & $\begin{array}{l}\text { very } \\
\text { severe b }\end{array}$ & none & $\begin{array}{l}12 / 297 \\
(4.0 \%)\end{array}$ & $\begin{array}{l}12 / 304 \\
(3.9 \%)\end{array}$ & $\begin{array}{l}\text { not esti- } \\
\text { mable }\end{array}$ & $\begin{array}{l}10 \text { less per } \\
1,000 \\
\text { (from } 40 \\
\text { less to } 20 \\
\text { more) }\end{array}$ & $\begin{array}{l}\text { ФOOO } \\
\text { VERY } \\
\text { LOW }\end{array}$ & $\begin{array}{l}\text { IM- } \\
\text { PORT- } \\
\text { ANT }\end{array}$ \\
\hline \multicolumn{13}{|c|}{ MORTALITY } \\
\hline 5 & $\begin{array}{l}\text { ran- } \\
\text { domized } \\
\text { clinical } \\
\text { trials }\end{array}$ & severe a & $\begin{array}{l}\text { not } \\
\text { severe }\end{array}$ & $\begin{array}{l}\text { not } \\
\text { severe }\end{array}$ & $\begin{array}{l}\text { very } \\
\text { severe b }\end{array}$ & none & $\begin{array}{l}79 / 418 \\
(18.9 \%)\end{array}$ & $\begin{array}{l}88 / 418 \\
(21.1 \%)\end{array}$ & $\begin{array}{l}\text { not esti- } \\
\text { mable }\end{array}$ & $\begin{array}{l}20 \text { more } \\
\text { per } 1,000 \\
\text { (from } \\
\text { minus } \\
40 \text { to } 70 \\
\text { more) }\end{array}$ & $\begin{array}{l}\oplus O O O \\
\text { VERY } \\
\text { LOW }\end{array}$ & $\begin{array}{l}\text { IM- } \\
\text { PORT- } \\
\text { ANT }\end{array}$ \\
\hline \multicolumn{13}{|c|}{ PROGRESSION OF THE DISEASE } \\
\hline 3 & $\begin{array}{l}\text { ran- } \\
\text { domized } \\
\text { clinical } \\
\text { trials }\end{array}$ & severe a & $\begin{array}{l}\text { not } \\
\text { severe }\end{array}$ & \begin{tabular}{|l} 
not \\
severe
\end{tabular} & severe b & none & $\begin{array}{l}21 / 350 \\
(6.0 \%)\end{array}$ & $\begin{array}{l}31 / 349 \\
(8.9 \%)\end{array}$ & $\begin{array}{l}\text { not esti- } \\
\text { mable }\end{array}$ & $\begin{array}{l}20 \text { more } \\
\text { per } 1,000 \\
\text { (from } \\
\text { minus } \\
10 \text { to } 60 \\
\text { more) }\end{array}$ & $\begin{array}{l}\oplus \oplus \bigcirc \bigcirc \\
\mathrm{LOW}\end{array}$ & $\begin{array}{l}\text { IM- } \\
\text { PORT- } \\
\text { ANT }\end{array}$ \\
\hline
\end{tabular}

$\mathrm{Cl}$ : Confidence interval. a. Biases in the blinded allocation, losses, blinding, prognostic characteristics, and sample size calculation b. Wide confidence interval

TABLE 5. PAPERS EXCLUDED

\begin{tabular}{l|l}
$\begin{array}{l}\text { List of papers ex- } \\
\text { cluded }\end{array}$ & Reason for exclusion \\
\hline Tan 2019 & SR/meta-analysis \\
\hline Mokdad 2017 & Descriptive study \\
\hline Majumdar 2017 & SR \\
\hline Lou 2017 & SR \\
\hline Facciorusso 2016 & SR \\
\hline Yi Y 2014 & RCT with combined chemoembolization \\
\hline Galandi D 2004 & SR \\
\hline Gaiani S 2003 & Article of treatment review \\
\hline Glassberg 2019 & SR \\
\hline
\end{tabular}

SR: Systematic review. RCT: Randomized clinical trial
FIGURE 1. FLOWCHART OF THE STUDIES RETRIEVED AND SELECTED ON THE USE OF MICROWAVE ABLATION VERSUS RADIOFREQUENCY ABLATION IN HEPATOCELLULAR CARCINOMA

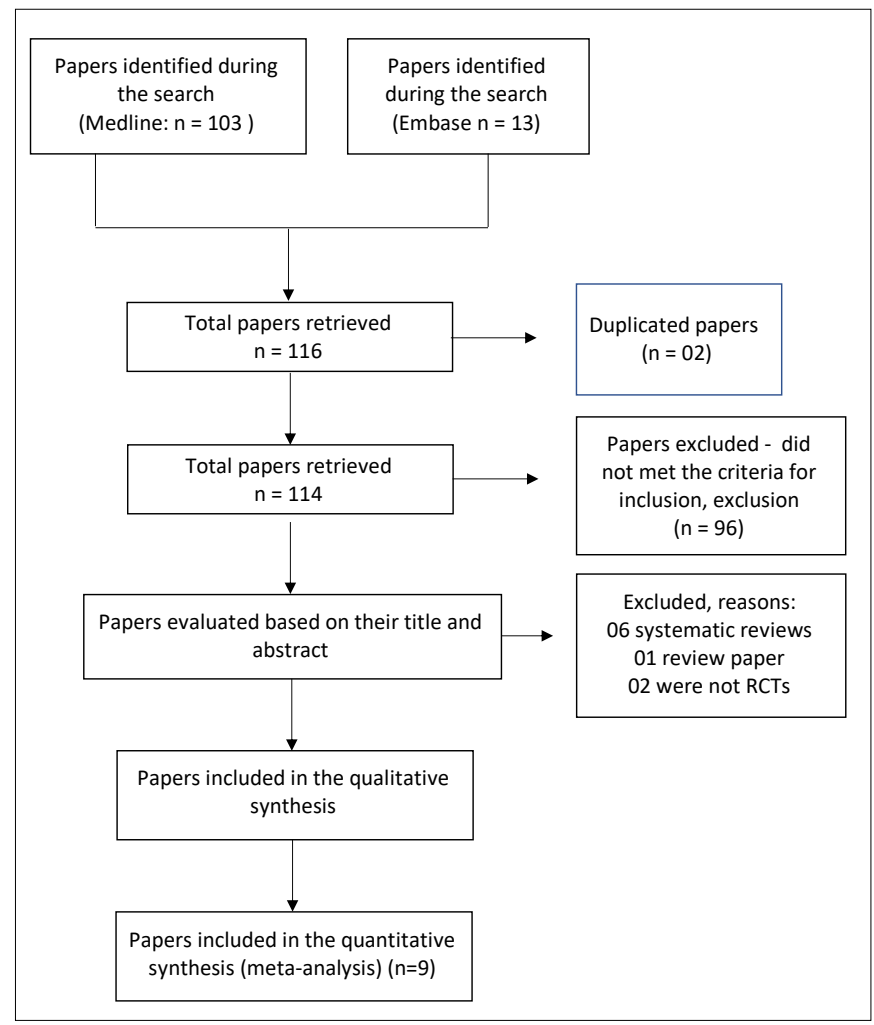




\section{Characteristics of the studies included}

1. A total of 56 patients were selected with hepatocellular carcinoma and lesions $\leq 3.0 \mathrm{~cm}$, without lesions larger than $5.0 \mathrm{~cm}$, vascular invasion, or extra-hepatic metastases. A total of 28 underwent treatment by radiofrequency ablation, and 28 by microwave ablation. The outcomes were assessed based on local recurrence, mortality, and complications. The follow-up time was 12 months 5 .

2. Of the 152 patients selected with hepatocellular carcinoma, 76 underwent treatment by radiofrequency ablation, and 76 by microwave ablation. The evaluation was carried out by analysis of the protocol. Five patients were excluded from the group of microwave ablation and three from the group of radiofrequency ablation. The outcomes evaluated were: mortality and progression of the disease. The follow-up time was 26 months in the microwave ablation group and 25 months in the radiofrequency ablation group ${ }^{6}$.

3. A total of 403 patients with hepatocellular carcinoma, with the following information: tumor size $\leq 5 \mathrm{~cm}$ in diameter, number of tumors $\leq 3$, Child-Pugh class A or B, without evidence of extra-hepatic metastasis, tumor embolism of veins or the bile duct, lesions visible on ultrasound with an acceptable puncture path. A total of 200 patients underwent treatment by radiofrequency ablation, and 203 by microwave ablation. The outcomes evaluated were: mortality, complications, and progression of the disease. The follow-up time was 36 months ${ }^{7}$.

4. A total of 72 patients were selected with hepatocellular carcinoma and lesions smaller than $4 \mathrm{~cm}$ in diameter or with two or three nodules smaller than or equal to $3 \mathrm{~cm}$ in diameter. A total of 36 patients underwent treatment by radiofrequency ablation, and 36 by microwave ablation. The outcomes evaluated were: local recurrence and complications. The follow-up time was 18 months $^{8}$.

5. A total of 111 patients were selected with early-stage hepatocellular carcinoma and preserved liver function (Child-Pugh A and B), performance status 0 , and with 3 or less focal lesions (the larger of which not exceeding $5 \mathrm{~cm}$ in size). A total of 45 patients underwent treatment by radiofrequency ablation, and 66 by microwave ablation. The outcomes evaluated were: local recurrence, complications, and mortality. The follow-up time was 27 months 9 .

6. A total of 40 patients were selected with a single hepatocellular carcinoma tumor $>2.0$ and $<7,0 \mathrm{~cm}$ diameter, located $\geq 3.0 \mathrm{~cm}$ away from the capsule of the liver, gallbladder, main left or right hepatic ducts or main vessels. A total of 20 patients underwent treatment by radiofrequency ablation, and 20 by microwave ablation. The evaluated outcome was complications. The follow-up time was not reported ${ }^{10}$.

7. A total of 50 patients were included with ChildPugh class A or B, serum albumin $\geq 3 \mathrm{~g} / \mathrm{l}$, serum bilirubin $<2.5 \mathrm{mg} / \mathrm{dl}$, platelet count $\geq 70,000 \mathrm{~mm} 3$, international normalized ratio (INR) $\leq 1.6$, serum creatinine $<2 \mathrm{mg} / \mathrm{dl}$, and tumor size greater than $4 \mathrm{~cm}$, and confined to one lobe of the liver. The patients were randomized as follows: 20 for arterial chemoembolization, 20 for arterial chemoembolization combined with radiofrequency ablation, and 10 for arterial chemoembolization combined with microwave ablation. The outcomes evaluated were: local recurrence and complications. The follow-up time was 6 months ${ }^{11}$.

8. A total of 144 patients with chronic liver disease with HCC $\leq 4 \mathrm{~cm}$, BCLC stage A, not eligible for surgery were evaluated. Of these, 73 were treated with radiofrequency ablation, and 71 with microwave ablation. The outcomes evaluated were: survival (mortality), complications, and disease progression. The follow-up time was 20 months ${ }^{12}$.

9. A total of 81 patients were selected with hepatocellular carcinoma and averages lesions of $3.0 \mathrm{~cm}$. A total of 41 patients were treated with radiofrequency ablation, and 40 with microwave ablation. The outcomes evaluated were: local recurrence and mortality. The follow-up time was 6 months ${ }^{13}$.

\section{Risk of bias and quality of evidence}

1. The randomization, prognostic characteristics, and outcomes were adequate; however, the allocation was not blinded, there was no double-blinding, and there is no description of losses or sample size calculation. There was no early interruption ${ }^{5}$.

2. Demonstrated adequacy of randomization, prognostic characteristics, outcomes, sample size calculation, and description of losses; however, there was no double-blinding and no description of how patients were allocated. There was no early interruption ${ }^{6}$.

3 . The randomization was performed, prognostic characteristics and outcomes are described; the allocation was not blinded, there was no double-blinding, and there is no description of losses or sample size calculation. There was no early interruption ${ }^{7}$.

4. The randomization and outcomes were adequate; there was no blinded allocation, no double-blinding, and there is no description of losses or of prognostic 
characteristics or sample size calculation. There was no early interruption. The analysis of intention-to-treat was carried out.

5 . The randomization process was inadequate (by currency) and there were losses greater than $20 \%$; the prognostic characteristics and outcomes were adequate; there was no blinded allocation, blinding, or sample size calculation; there was no early interruption or analysis by intention to treat ${ }^{9}$.

6. A randomized study with losses below $20 \%$, in which the prognostic characteristics and outcomes were adequate; there was no blinded allocation, and only the evaluators were blinded; there is no sample size calculation; there was no early interruption or analysis by intention to treat ${ }^{10}$.

7. Although the randomization and outcomes presented are adequate and there were no losses greater than $20 \%$, the blinded allocation, blinding, and sample size calculation were not carried out, and there is no description of the prognostic characteristics. The evaluation was performed by analysis of intention to treat and there was early interruption ${ }^{11}$.

8. Randomized study; the information was obtained from the summary, which is limited only to the appropriate outcomes and does not clarify on other risks of bias ${ }^{12}$.

9. Data obtained from the summary of this randomized study provide information on the outcomes but not on the risks of bias ${ }^{13}$.

\section{Analysis of results by outcomes}

We describe the meta-analyzed results of the following outcomes: local recurrence, mortality, complications, and disease progression:

Local recurrence

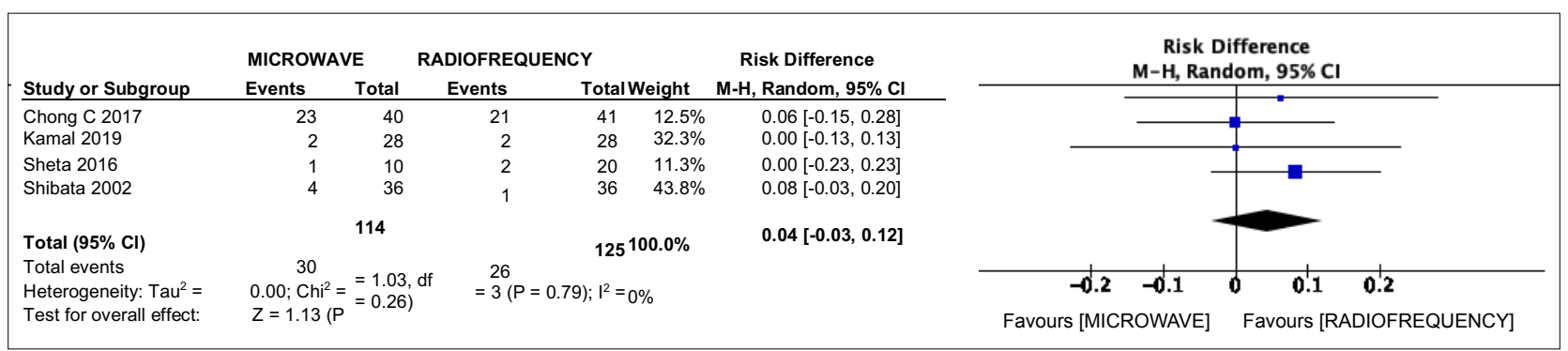

There is no difference (greater or lesser effectiveness) in relation to the outcome of local recurrence when comparing the use of microwave and radiofrequency [risk difference 0.04 (- 0.03 to 0.12)].

\begin{tabular}{|c|c|c|c|c|c|c|c|c|}
\hline Study or Subgroup & \multicolumn{5}{|c|}{ MICROWAVE RADIOFREQUENCY } & \multirow{2}{*}{$\begin{array}{l}\text { Risk Difference } \\
\text { M-H, Random, } 95 \% \mathrm{Cl}\end{array}$} & \multicolumn{2}{|c|}{$\begin{array}{c}\text { Risk Difference } \\
\text { M-H, Random, } 95 \% \mathrm{Cl}\end{array}$} \\
\hline Chong C 2017 & $\begin{array}{r}\text { Events } \\
15\end{array}$ & $\begin{array}{r}\text { Total } \\
40\end{array}$ & $\begin{array}{r}\text { Events } \\
22\end{array}$ & 41 & $5.8 \%$ & & & - \\
\hline Kamal 2019 & 4 & 28 & 4 & 28 & $7.9 \%$ & $0.00[-0.18,0.18]$ & . & \\
\hline Nai'k W 2017 & 8 & 71 & 9 & 73 & $23.9 \%$ & $-0.01[-0.12,0.09]$ & & \\
\hline Viettti Violi 2018 & 15 & 76 & 15 & 76 & $16.6 \%$ & $0.00[-0.13,0.13]$ & 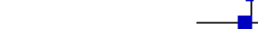 & _ \\
\hline Yu J 2017 & 37 & 203 & 38 & 200 & $45.9 \%$ & $-0.01[-0.08,0.07]$ & & \\
\hline Total $(95 \% \mathrm{Cl})$ & & 418 & & 418 & $100.0 \%$ & $-0.02[-0.07,0.04]$ & & \\
\hline Total events & 79 & & 88 & & & & & \\
\hline Heterogeneity: $\mathrm{Tau}^{2}=$ & $0.00 ; \mathrm{Chi}^{2}=$ & $=1.97, \mathrm{df}$ & $=4(P=$ & $0.74) ; 1^{2}=0 \%$ & & & $\begin{array}{ccc}-0.2 & -0.1 & 0\end{array}$ & $\begin{array}{lll} & 0.1 & 0.2 \\
& 1\end{array}$ \\
\hline
\end{tabular}

There is no difference between the two forms of treatment in relation to the outcome of mortality (risk difference -0.02 [-0.07 to 0.04]) 
Complications

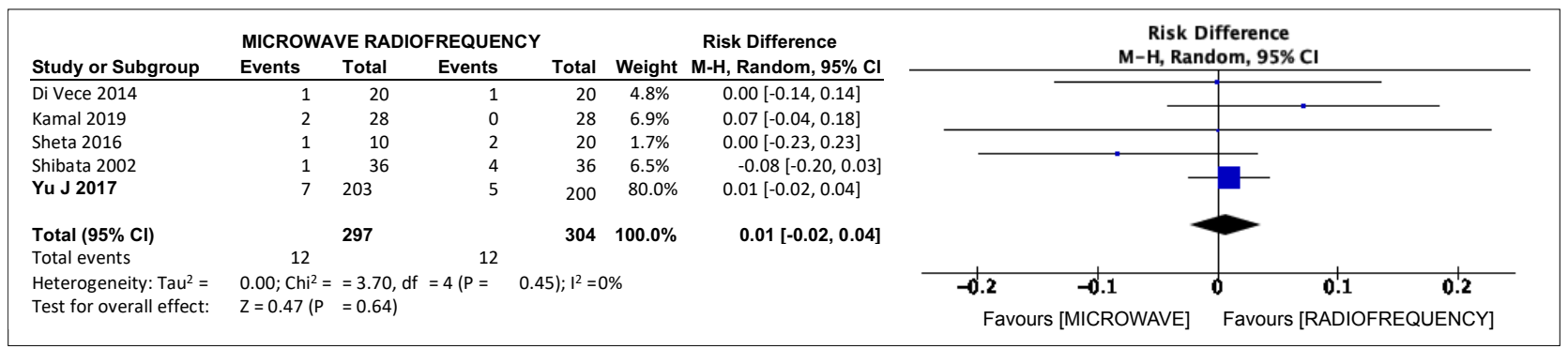

There is no difference between the two forms of treatment in relation to the outcome of complications (risk difference 0.01 [-0.02 to 0.04])

Progression of the disease

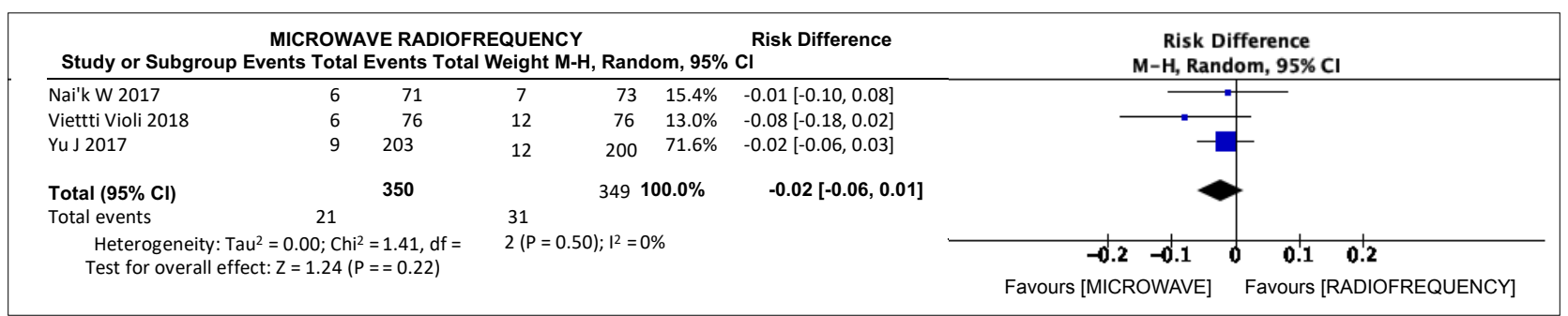

There is no difference between the two forms of treatment in relation to the outcome of progression of the disease (risk difference -0.02 [-0.07 to 0.01]).

\section{QUALITY OF EVIDENCE}

The quality of the evidence for all outcomes (local recurrence, mortality, disease progression, and complications) is very low (TABLE 4).

\section{SYNTHESIS OF EVIDENCE}

There are no differences between the use of microwave ablation in comparison with radiofrequency ablation in the treatment of hepatocellular carcinoma lesions $\leq 5.0 \mathrm{~cm}$ regarding the outcomes: local recurrence, mortality, complications, and progression of the disease. This means that it is not known whether the efficacy or safety is greater or SMALLER than those of the treatment already in use (radiofrequency). The quality of the evidence is very low.

\section{REFERENCES}

1. European Association For The Study Of The Liver; European Organisation For Research And Treatment Of Cancer. EASL-EORTC clinical practice guidelines:management of hepatocellular carcinoma. J Hepatol. 2012 Apr;56(4):908-43. doi: 10.1016/j.jhep.2011.12.001. Erratum in: J Hepatol. 2012 Jun;56(6):1430. PubMed PMID: 22424438.

2. Guyatt $G H$, Oxman $A D$, Schünemann HI, Tugwell P, Knottnerus A. GRADE guidelines:a new series of articles in the Journal of Clinical Epidemiology. J Clin Epidemiol. 2011 Apr;64(4):380-2. doi: 10.1016/j.jclinepi.2010.09.011. Epub 2010 Dec 24. PubMed PMID: 21185693.

3. Review Manager (RevMan) [Computer program]. Version 5.3. Copenhagen: The Nordic Cochrane Centre, The Cochrane Collaboration, 2014.

4. GRADEpro GDT: GRADEpro Guideline Development Tool [Software]. McMaster University, 2015 (developed by Evidence Prime, Inc.). Available from gradepro.org.

5. Kamal A, Elmoety AAA, Rostom YAM, Shater MS, Lashen SA. Percutaneous radiofrequency versus microwave ablation for management of hepatocellular carcinoma: a randomized controlled trial. | Gastrointest Oncol. 2019 Jun;10(3):562-571. doi: 10.21037/jgo.2019.01.34. PubMed PMID: 31183208; PubMed Central PMCID: PMC6534711.

6. Vietti Violi N, Duran R, Guiu B, Cercueil JP, Aubé C, Digklia A, Pache I, Deltenre $P$, Knebel JF, Denys A. Efficacy of microwave ablation versus radiofrequency ablation for the treatment of hepatocellular carcinoma in 
patients with chronic liver disease: a randomised controlled phase 2 trial. Lancet Gastroenterol Hepatol. 2018 May;3(5):317-325. doi: 10.1016/S24681253(18)30029-3. Epub 2018 Mar 2. PubMed PMID: 29503247.

7. Yu J, Yu XL, Han ZY, Cheng ZG, Liu FY, Zhai HY, Mu MJ, Liu YM, Liang P. Percutaneous cooled-probe microwave versus radiofrequency ablation in early-stage hepatocellular carcinoma: a phase III randomised controlled trial. Gut. 2017 |un;66(6):1172-1173. doi: 10.1136/gutjnl-2016-312629. Epub 2016 Nov 24. PubMed PMID: 27884919; PubMed Central PMCID: PMC5532455.

8. Shibata $T$, limuro $Y$, Yamamoto $Y$, Maetani $Y$, Ametani F, Itoh K, Konishi Small hepatocellular carcinoma: comparison of radio-frequency ablation and percutaneous microwave coagulation therapy. Radiology. 2002 May;223(2):331-7. PubMed PMID: 11997534.

9. Abdelaziz A, Elbaz T, Shousha HI, Mahmoud S, Ibrahim M, Abdelmaksoud A, NabeelM. Efficacy and survival analysis of percutaneous radiofrequency versus microwaveablation for hepatocellular carcinoma: an Egyptian multidisciplinary clinic experience. Surg Endosc. 2014 Dec;28(12):3429-34. doi: 10.1007/s00464-014-3617-4.Epub 2014 Jun 17. PubMed PMID: 24935203
10. Di Vece F, Tombesi P, Ermili F, Maraldi C, Sartori S. Coagulation areasproduced by cool-tip radiofrequency ablation and microwave ablation using a device to decrease back-heating effects: a prospective pilot study. Cardiovasc Intervent Radiol. 2014 Jun;37(3):723-9. doi: 10.1007/s00270-013-0733-9. Epub 2013 Oct 3. PubMed PMID: 24196263

11. Sheta E, El-Kalla F, El-Gharib M, Kobtan A, Elhendawy M, Abd-Elsalam S, Mansour L, Amer I. Comparison of single-session transarterial chemoembolization combined with microwave ablation or radiofrequency ablation in the treatment of hepatocellular carcinoma: a randomized-controlled study. Eur | Gastroenterol Hepatol. 2016 Oct;28(10):1198-203. doi: 10.1097/ MEG.0000000000000688. PubMed PMID: 27362551.

12. Naïk V.V.; Rafael D.; Boris G.; Christophe A.; lean-Pierre C.; Pierre B.; Isabelle P.; Pierre D.; Jean-François K.; Alban D. Microwave ablation and radiofrequency ablation for the treatment of hepatocellular carcinoma: Result of the first prospective randomized controlled trial Annals of Oncology (2017) 28 Supplement 3 (iii6). Date of Publication: 1 Jun 2017

13. Chong C.; Fong A.; Chu C.; Yu S.; Fung A.; Lok H.-T.; Cheung S.; Wong J.; Lee K.-F.; Lai P. Microwave versus radiofrequency ablation for hepatocellular carcinoma: A randomized controlled trial... ournal of Hepato-Biliary-Pancreatic Sciences (2017) 24 Supplement 1 (A194). Date of Publication: 1 May 2017 